\title{
THE LINK AND MATCH MODEL OF NON FORMAL EDUCATION
}

\author{
Oong Komar \\ ${ }^{\mathrm{a} D e p a r t m e n t ~ o f ~ N o n ~ F o r m a l ~ E d u c a t i o n, ~ F a c u l t y ~ o f ~ E d u c a t i o n ~ S c i e n c e s, ~ U n i v e r s i t a s ~ P e n d i d i k a n ~ I n d o n e s i a ~}$ \\ Corresponding e-mail: oongkomar@yahoo.com
}

\begin{abstract}
The research titled "A Study of the Relationship between Academic Performance and Competence/Job Performance of Nonformal Education Study Program" is prompted by the absolute need for competence because the challenges in the future are increasingly complex, ultimately due to the increasingly intense competition that requires highly complex and risky provision of services/products. Competition is no longer at the local level only, but also regional and international levels, thereby necessitating efforts of improving the quality in encountering employment competition. The present research aims to analyse the relationship between qualifications of a study program through the formulation of competence/job performance and the difficulties encountered by graduate users in describing the jobs appropriate for graduates of Non Formal Education Study Program. The research will provide solutions to the future challenges concerning the increasingly intense competition in complex and risky provision of services/products, which absolutely requires improvement in the quality of the competence to face competition in employment, not only at the local, but also regional and international levels. It adopted a survey approach using the techniques of interviews and questionnaire distributed to a sample of research objects, namely an non formal education study program and its graduates. The research resulted in a model of the relationship between qualifications of out-of-school education study program and the competence of its graduates as a recommendation for the improvement of the quality of non-formal education services in the coming years.
\end{abstract}

Keywords: qualification, competence, academic performance, job performance.

\section{INTRODUCTION}

Education and employment are two different worlds which never intersect. The participation rate and the increased number of university graduates as well as the rate of university graduates' unemployment show no improvement in work productivity.

The gap between supply and demand of university graduates essentially cannot be measured by number because actually there is still a lack of university graduates. It is probable that there is a mismatch between the jobs needed in the field and the types of expertise produced by higher education institutions.

Data show there is a tendency that the higher the education level, the greater the rate of unemployment. The tendency for senior high school graduates to be unemployed is higher than that of graduates of junior high school and the lower levels.

Darlaini Nasution, S.E. explained there are three fundamental factors causing a high rate of unemployment in Indonesia: The gap between the output of education and the jobs in the field, imbalance between demand and supply, and low quality of human resources. Consequently, the available jobs in the market do not match with most graduates' education levels or skills.

According to the theory of Human Capital, it is explained that education has an effect on economic growth, considering its role in increasing work productivity.

The theory of Human Capital sees formal education as a form of investment for individuals and society. Education serves as a supplier of educated and trained labor. The function can be tested based on its ability in meeting the amount of labor needed by the existing employment or by the amount of employment predicted to be available in an economic system. To test this ability, a comparison between the available workforce produced by education and training system and the need for workforce in the employment should be made according to the categories of workforce education levels.

The intersection between education and employment is work productivity, with an assumption that the higher the quality of education, the higher work productivity, and the higher the impact on the economic growth of a community. The growth of a community should begin from individuals' productivity. If every individual has a 
high income because of high education level, the growth of the community can also be supported accordingly.

Pressing the increasing number of unemployed college graduates with Link and Match model means improving the relevance of education to the needs of employment, business, and industry. The implementation of professional skill education systematically and synchronously integrates education program and skill mastery program obtained through direct work experience in the field to achieve a level of professional expertise.

There are three components necessary to make the link and match model successful: Universities, corporations and government. In addition, first, it is important not to regard "link and match" model as a preparation of handymen. The "link and match" model should be understood as a linkage and matchmaking in responding to progress. Changes will be immutable. Education therefore must prepare: (1) critical thinking skills; (2) the development of creative thinking skills; and (3) development of innovative thinking ability.

Second, it is important not to understand "link and match" merely as alignment of education with employment. The paradigm of "link and match" should be drawn more broadly on the relevance and compatibility between education and life; in other words, what is needed in life must certainly be the same as what is needed by employment.

The "link and match" model suggests that graduates acquire insight or competitiveness, such as work ethic, motivation to achieve, mastery, competitiveness, money belief, and attitudes to saving.

"Link and match" requires a change of mindset of all education administrators, both the educational institutions and teaching staff, about the world of work or employment, such as changing the mindset from being satisfied by merely issuing diplomas to being proud to provide competence.

It is time to work together to build competencies. Without competence built through "link and match" between education and the industry, then all equipment, building, and investment will not be maximally used. In fact, many school buildings with their sophisticated equipment do not work properly because no experts can run the equipment.

\section{RESEARCH METHOD}

\subsection{Research Method}

Research approach in general is classified into two. The first research approach is based on the tendency of the level of generalization of findings, categorized into census, survey, and case study research approaches. Meanwhile, the second type of approach is based on kinds of report analysis techniques employed, included under this category are exploratory, descriptive, and explanatory (correlational, experimental) research approaches [1]

Based on the above classifications, the present research investigating the link between the qualification of non-formal education study program and the competences of its graduate workforce can be categorized as survey research. Furthermore, by considering the research goal and instrument of data collection, the present research is included under the category of cross-sectional study and exploratory research.

\subsection{Aim}

The research aims to investigate the relationship between the qualification of non-formal education study program and the competences of its graduates who have entered employment. Hence, the research attempted to assess the opinions of graduate users, with the method of survey and data collection techniques of interview and questionnaires regarded to be appropriate for the nature of the research aims.

\subsection{Time and Location}

The research took place from April to November 2015. It was conducted in Bandung City and Bandung Barat Regency, West Java Province.

\subsection{Research Subject}

The respondents were divided into three large groups of education personnel, namely:

1. Management staff of an education unit, namely the human resources who are given the authority and responsibility to lead a unit of education (in this regard, they are school/Madrasah principals, rectors, directors, and the like).

2. Educators, namely human resources participating in the implementation of education with the special task of educating students. Educators have other names specific to the level and type of education they teach, namely teacher, lecturer, tutor, counsellor, instructor, facilitator, ustadz/dzah, and other titles.

3. Education personnel, namely human resources participating in the administration of education in a 
unit of education, although they are not directly involved in the education process; they are, among others: Administration staff, laboratory technicians, librarians, and the like.

The research determined that the population target included related parties and stakeholders of non-formal education study program and the accessible population consisted of parties related to the Non formal Education Study Program of the School of Postgraduate Studies of Universitas Pendidikan Indonesia or Indonesia University of Education (UPI). The respondents, selected purposively, included: four users of graduates (Heads of Non-formal/Informal Education of Bandung City and Bandung Barat Regency, Head of Ash-Shoddiq Community Learning Centre, and Head of Learning House) and two graduates of Non formal Education Study Program, UPI, from the 2011 and 2010 batches.

\section{RESULT AND DISCUSSION}

Many alumni of Non formal Education Study Program of UPI (Indonesia University of Education) who work in Government and institutions Private have high academic competence. The largest users of Non formal Education Study Program are government agencies. While it is not yet certain that promotion or salary increase of alumni is an indication of the quality of the study program's graduates, the fact at least suggests that knowledge and graduate degrees have a positive impact on career development in the workplace.

This is in accordance with the opinion that the implementation of education and teaching certainly has a goal, without the goal of the implementation of education and teaching will not produce competent graduates [2]

The academic performance of a study program is demonstrated through the competence of motivating community inspiration, initiating the anticipation of environmental change, identifying opportunities and problem solving, negotiating-consultingdirecting/coordinating activities with other parties, and following up policies with implementation and monitoring to assess their effectiveness.

Meanwhile, the job performance of a study program is demonstrated through the skills of organizational management, managerial identification-analysis and interpretation, being sensitive to environmental issues, resolving conflicts by developing consensus, providing required advice and input, and creating networks by maximizing information technology.

Based on skills and expertise, the professionalism of graduates of non-formal education study program can be demonstrated through the ability to: motivate, adapt to environmental changes, identify opportunities, coordinate activities with others, follow up policies, conduct information analyses, be sensitive to problems in the environment, develop consensus, provide advice and input as needed, manage priorities in accordance with the targeted time, and maximize information technology.

Non formal education has an institutional purpose that allows citizens to have; 1) the opportunity to develop personality and selfactualization; 2) the ability to face the challenges of life both within the family and community environment; 3) the ability to foster prosperous families to promote the common good; 4) a broad insight into the rights and obligations of citizens; 5) kemmapuan awareness of nation, state, and society in the framework of human and community development; 6) the ability to create or help create employment in accordance with the expertise they have [3]

Finally, the development of managerial competence can be demonstrated through: The process of developing the knowledge, attitude, skills, and behaviors according to managerial functions implemented in managing an organization so that the individual acts effectively, creatively, and innovatively. Continuous competence development is necessary in order to keep up with environmental changes and development, by continuously being creative to produce innovative products in accordance with the needs of the community.

\section{CONCLUSIONS AND SUGGESTION}

The research has revealed which academic performance tends to fit in professional-academic field and which one less suitable with the economic growth at both the national and international levels. It has also shown which job competence or performance tends to fit the needs of practitioner users and which one less suitable with the government as user. The conclusion of the results indicates a mismatch between the qualifications of the non-formal study program under research with the competence of graduates joining the workforce; furthermore, graduate users have difficulty in describing the appropriate job descriptions. The 
results of this research can be made recommendations for the development of service quality of the non-formal study program in the coming years.

\section{REFERENCES}

[1] Anggoro, M. T. (2007) Metode Penelitian (Research Method). Jakarta: UT Press.

[2] Purwanto, Ngalim . (2011). Ilmu Pendidikan Teoritis Dan Praktis. Bandung: Remaja Rosdakarya.

[3] Gitoasmoro, Sogimin (2005), Peran Pendidikan Non Formal Dalam Realisasi Wajib Belajar Pendiidkan Dasar. Jurnal Pendidikan Dasar, Vol 6 No 1.

[4] G. Eason, B. Noble, \& I.N. Sneddon, “On certain integrals of Lipschitz-Hankel type involving products of Bessel functions," Phil. Trans. Roy. Soc. London, vol. A247, pp. 529551, April 1955. (references)

[5] Becker, G.S. (1994) Human Capital. Chicago: The University of Chicago Press.

[6] Chapter 28A.150 (2010) Basic Education. Washington State Legislature.

[7] Daliyo. (1998) Pekerja Anak dan Perencanaan Pendidikan di Nusa Tenggara barat dan Timur (Child Workers and Education Planning in Nusa Tenggara Barat and Timur). Jakarta: USAID.

[8] Geist, J. R. (2002). Predictor of Faculty Trust in Elementary School (Unpublished Disertation). The Ohio State University, USA.

[9] Hanke J, E.. \& Wichem, D.W. (2005) Business Forecasting. Pearson Prentice Hall.

[10]Komar, O. (2003) Menemukan dan Mengembangkan Peta Ilmu Pendidikan (Finding and Developing Education Science Map). Research Report. Bandung: UPI.

[11] Mangan, J. (1980). Pengaruh Sekolah pada Masyarakat Tradisional Indonesia (The impact of school on Indonesian Traditional Society). Prisma No. 2. Tahun XV.

[12] Notodihardjo, H. (1999). Pendidikan Tinggi dan Tenaga Kerja Tingkat Tinggi (Higher Education and High Level of Labor). Jakarta. UI Press

[13] Pramono, M. (2003). Dasar-Dasar Filosofis Ilmu Olah raga (Philosophical Foundations of Sport Science). Surabaya Unesa.

[14] Satori, D. (1992). Pengelolaan Pendidikan luar sekolah (Non formal Education Management). Prosiding Saresehan ISPI. Bandung: ISPI.

[15] Strategic Plans of Department of National Education. 2010-2014.
[16] Surakhmad, W. (1986). Ilmu Pendidikan untuk Pembangunan (Education Science for Development). Prisma No. 2. Volume XV. 